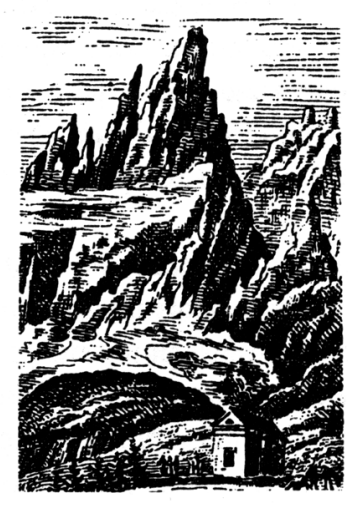

Monika Witt

Państwowa Wyższa Szkoła Zawodowa w Nysie

monika.witt@pwsz.nysa.pl

DOI: 10.19195/2084-4107.11.22

\title{
Przeżycie górskie jako rozmycie granic w Nieuchwytnych szczytach Victora Saundersa i Czterech dniach stońca Adama Skoczylasa
}

Słowa-klucze: Góry, alpinizm, himalaizm, literatura górska

Keywords: mountains, Alpine mountaineering, Himalayan mountaineering, mountain literature

Experiences in the mountains as blurring of the borders in Victor Saunders' Elusive Summits and Adam Skoczylas' Cztery dni stońca

\section{Summary}

The article is an analysis of Adam Skoczylas' Cztery dni stońca (Four Days of Sunshine) and Victor Saunders' Elusive Summits, works that are part of mountain literature, the boundaries of which are set, on the one hand, by the unique context of writing involving a close relation between life and work; and on the other by unique reception involving a relation between the author and 
the reader based on shared experiences, on which this reception depends. The factor that became a condition for the emergence of such literature was a unique way of looking at the mountains, characteristic of mountaineers exploring the Tatras, the Alps and then also the Himalayas. It becomes a starting point for narrative as well as a condition for forming a reader group. A characteristic feature of the works discussed in the article is their narrative emphasising the intensity of sensations accompanying experiences in the mountains.

Podsumowując wyprawę na Uzum Brakk, znany również pod nazwą Ogre szczyt w Karakorum, Victor Saunders pisze:

W gruncie rzeczy, to nie wiem, czy na Uzum Brakk odnieśliśmy sukces. Cóż w zasadzie jest jego wyznacznikiem? Jakimi kryteriami można oceniać naszą ekspedycję? Czy spełniła ona chociaż te najbardziej obiektywne: zdobycie szczytu; dostarczenie wspaniałych przeżyć, cokolwiek by to miało oznaczać; bezpieczny powrót. W odwrotnej oczywiście kolejności ${ }^{1}$.

$\mathrm{Z}$ tego rodzaju rozważaniami często spotykamy się w literaturze górskiej tworzonej przez „,piszących wspinaczy”, czyli ludzi będących w pierwszym rzędzie wspinaczami (alpinistami, taternikami czy himalaistami), dla których twórczość literacka jest sposobem relacjonowania przeżyć górskich. Dla autorów książek z tego obszaru literatury legitymację stanowi fakt dokonania czegoś szczególnego w górach, estetyczno-literackie walory zaś nie grają pierwszoplanowej roli w recepcji ich utworów. Cytowany fragment Nieuchwytnych szczytów Victora Saundersa dotyczący refleksji nad wyprawą na Uzum Brakk zapowiada jednak pewną specyficzną perspektywę pisarską, odmienną od kojarzonej zwykle z tym obszarem literatury górskiej, w której eksponowane są wymierne osiągnięcia, co zapowiadają już takie tytuły, jak: Poniżej i powyżej 8000 metrów Hermanna Buhla, Zwyciężý znaczy przeżyć Aleksandra Lwowa, Siódmy stopień Reinholda Messnera czy powtarzające się w dwóch tytułach książek polskich himalaistów „14x8000”: Mój pionowy świat, czyli $14 x 8000$ metrów Jerzego Kukuczki oraz Korona Himalajów 14x8000 Krzysztofa Wielickiego. Eksponowanie w pisarstwie wymiernych osiągnięć koresponduje oczywiście z nastawieniem na współzawodnictwo w samej działalności górskiej. Wydaje się jednak, że mamy tu do czynienia z pewną konwencją wywierającą wpływ na narracje także w relacjach dotyczących przeżyć o innym charakterze, których autorzy nie charakteryzują się postawą skupioną jednoznacznie na współzawodnictwie. Ciekawe może być w tym kontekście stwierdzenie Wojtka Kurtyki będące podsumowaniem jego artykułu o polskim himalaizmie, a zarazem własnej kariery himalajskiej. Kurtyka świadomie rezygnował z udziału w wielkich, nastawionych na wymierny sukces wyprawach himalajskich na rzecz wspinaczki w stylu alpejskim - z jednym lub dwoma partnerami. Swoje podejście przeciwstawia podejściu Jerzego Kukuczki, z którym przez jakiś czas się wspinał, mówiąc o nim,

1 V. Saunders, Nieuchwytne szczyty, przeł. D. Knysz-Rudzka, Kraków 1994, s. 55.

Góry, Literatura, Kultura 11, 2018

(C) for this edition by CNS 
że „urządził pierwsze igrzyska na ośmiotysięcznikach”2. Sam Kurtyka wyznaczył wiele nowych dróg w Himalajach, lecz jak pisze, ,ważniejsze są wspinaczki na świetlistych ścianach niższych szczytów"3. Pomimo to w zakończeniu jego pełnego cyfr tekstu o historii polskiego himalaizmu pojawia się następująca refleksja:

Podając tutaj te liczne cyfry, jestem w wielkim konflikcie między sportem, któremu cyfry służą, a sztuką, którą zabijają. Niestety wiem, że jest to odwieczny spór między próżnością a absolutem, i właśnie to, że po 20 latach wspinania wciąż się on we mnie toczy, jest jedyną moją porażką ${ }^{4}$.

W utworach, którymi pragnę się zająć, wartość przeżyć górskich nie jest mierzona przekraczaniem granic (wysokości, trudności czy też własnych granic fizycznych i psychicznych), lecz decyduje o niej intensywność; to właśnie oddanie nasycenia wrażeń i przeżyć staje się celem pisarstwa.

Takie podejście kojarzymy z klasyczną pozycją literatury tatrzańskiej, mianowicie Sześć dni w Tatrach. Wycieczka bez programu Tytusa Chałubińskiego. Już sam tytuł powstałego w 1878 r. dzieła sugeruje, że dla autora przebywanie w górach stanowi sens sam w sobie i nie musi zawierać programu zdobywczego. Nie należy mylić takiego podejścia z ideą turystyki masowej, w której turysta charakteryzujący się bierną postawą poznawczą podąża utartym szlakiem i czerpie przyjemność z przebywania w miejscach uznanych za piękne. Można tu przywołać opinię Luciusa Burckhardta, twórcy dziedziny nauki zwanej spacerologią $^{5}$, wedle którego dla turystów piękne jest to, co już zostało uznane za piękne ${ }^{6}$. Dowód na to twierdzenie możemy wywieść z własnego doświadczenia. Oglądając albumy ze zdjęciami z urlopu, stwierdzamy przecież, że oryginalne w mniemaniu autorów ujęcia krajobrazu, nie tylko górskiego, powtarzają się na każdym z nich. Jednak Chałubiński był zupełnie innym turystą — nie tylko ze względu na fakt, że działał w pionierskich czasach taternictwa, lecz także ze względu na swą postawę poznawczą. Jak zwraca uwagę Jacek Kolbuszewski we wstępie do wydania Sześciu dni w Tatrach z 1988 r., Chałubiński brał udział w wycieczkach po drogach sięgających najwyższych pokonywanych wówczas trudności skalnych 7 . Mimo to nie pokonywanie trudności jest osią opowieści, lecz przeżycia i wrażenia sześciu dni, dzięki dygresjom rozszerzone o wspomnienia z wielu innych wycieczek. Sam autor w kierowanym do „łaskawego czytelnika” zakończeniu tej eseistycznej relacji będącej jego jedyną pracą literacką określa jej cel jako „,skreślenie wrażeń”, notując:

2 W. Kurtyka, Polski syndrom, [w:] Wielkie wspinaczki: osobiste relacje najwybitniejszych ludzi gór, red. C. Bonington, A. Salkeld, przeł. K. Bockenheim et al., Bielsko Biała 1995, s. 200.

3 Ibidem, s. 205.

${ }^{4}$ Ibidem.

${ }^{5}$ W oryginalnej niemieckiej wersji językowej Spaziergangswissenschaft.

${ }^{6}$ L. Burckhardt, Warum ist Landschaft schön. Die Spaziergangswissenschaft, Berlin 2006, s. $33-41$.

7 Por. J. Kolbuszewski, Wstęp, [w:] T. Chałubiński, Sześć dni w Tatrach. Wycieczka bez programu, oprac. i komentarze R. Hennel, W.A. Wójcik, Kraków 1988, s. 10. 
pomimo wrodzonej powściągliwości pióra (muszę sobie oddać tę sprawiedliwość), pierwszy raz przedsięwziąłem skreślić moje wrażenia. Ale dla uspokojenia cię przyrzekam najuroczyściej, że się to nie powtórzy, choćby mi losy dozwoliły oglądać jeszcze nasze ukochane Tatry ${ }^{8}$.

Kolbuszewski we wstępie cytuje wypowiedź Witkiewicza:

w opowiadaniach innych taterników ciągle widać „przepaść niebezpieczną", grającą na duszy wędrowca choćby lekkim strachem, kiedy wrażenie tego „niebezpieczeństwa” opowiadający sili się udzielić czytelnikowi. [...] w opowiadaniu prof. Chałubińskiego ponad „otchłanią” unosi się łagodny spokojny uśmiech i dobroduszny humor. Zajęty obserwowaniem tej natury, pochłonięty przez wrażenia, nie odczuwa on ani niebezpieczeństw, ani trudów, ani niedostatku9 .

Kolbuszewski następnie stwierdza, że:

Spostrzeżenie Witkiewicza dotyczy zarazem sposobu prowadzenia narracji o górach w Sześciu dniach w Tatrach oraz chodzenia po nich jako istotnej cechy taternictwa Chałubińskiego ${ }^{10}$.

Stwierdzenie to z jednej strony można odnieść do specyficznej, uwypuklającej wrażenia i ich intensywność narracji łączącej dzieło Chałubińskiego z utworami, o których będzie mowa $\mathrm{w}$ niniejszym opracowaniu, $\mathrm{z}$ drugiej zaś strony to właśnie zgodność sposobu prowadzenia narracji ze sposobem działania w górach jest jednym z najważniejszych wyznaczników szerszego nurtu literatury górskiej, do której one należą. Zanim zajmę się ukazaniem ich szczególnego charakteru, chciałabym wyznaczyć ramy ograniczające obszar, w który wpisują się omawiane utwory. Poruszamy się w kręgu tekstów, w których autor relacjonuje swoje przeżycia w górach. Nasuwająca się tu jednak klasyfikacja tego typu literatury po prostu jako literatury faktu nie wydaje się oddawać jej specyfiki - nie tylko dlatego, że autorzy czasem dość swobodnie obchodzą się z opisem przeżyć, włączając $\mathrm{w}$ tok narracji, jak Chałubiński, eseistyczne dygresje dotyczące przeżyć z różnych miejsc i z różnego czasu. Główną różnicą, a zarazem elementem konstytuującym, jest tu kontekst tworzenia tekstów polegający na specyficznej relacji życia i pisarstwa. Hubert Jarzębowski, pisząc o taternickich bujdałkach, formie wypowiedzi literackiej wpisującej się w tenże nurt, stwierdza, że „mamy do czynienia z połączeniem tekstu opowiadania i tekstu kultury, którym jest pierwsze przejście wspinaczkowe"11. Utwory, o których mowa, w istocie często (choć nie zawsze) opowiadają o pierwszych przejściach lub przejściach spektakularnych $\mathrm{z}$ innych względów, a ich wyznacznikiem jest fakt, że autor przejścia jest zarazem

8 T. Chałubiński, op. cit., s. 86.

9 Cyt. za: J. Kolbuszewski, op. cit., s. 8.

10 Ibidem.

11 H. Jarzębowski, Bajdurzyć czyli mówić prawde, „Góry” 2013, nr 9, s. 79. 
autorem tekstu opowiadającego o nim. Pisarstwo jest więc zjawiskiem sekundarnym wobec działalności górskiej.

Kolbuszewski, pisząc o literaturze tatrzańskiej dwudziestolecia międzywojennego, stwierdza:

O ile w wieku XIX wystarczyło być pisarzem, aby być „taternikiem” i wówczas tylko kwestia indywidualnych dyspozycji twórczych decydowała o wartości działa literackiego, o tyle po zdobyciu Ostrego Szczytu, po wspięciu się na wierzchołek Orlej Baszty, pokonaniu zerw Żabiego Konia owa prawda gór, to znaczy prawdziwość ich wyglądu w najbardziej intymnie poznanej rzeczywistości, stawała się dostępna tylko dla wtajemniczonych w taternictwo ${ }^{12}$.

Ta „umiejętność analizy, oceny i rozumnego, świadomego zachwytu” oraz dostrzeganie szczegółu ${ }^{13}$, czyli umiejętność patrzenia na góry wyróżniająca taterników, alpinistów czy himalaistów, to kolejna cecha determinująca ich pisarstwo w sferze produkcji, lecz również determinująca jego recepcję i tym samym czyniąca je literaturą dla wąskiego kręgu „wtajemniczonych” odbiorców.

Z takim wyróżnieniem taterników poprzez kryterium, którym jest sposób patrzenia na góry, koresponduje teza autora licznych ekstrawaganckich eksperymentów dotyczących postrzegania krajobrazu, wspomnianego już Luciusa Burckhardta, który twierdzi, że krajobraz jest konstruktem i należy go szukać nie $\mathrm{w}$ otoczeniu, lecz $\mathrm{w}$ głowach postrzegających $\mathrm{go}^{14}$. Krajobraz zależy zatem od nastawienia, doświadczeń i wiedzy osoby konstruującej go, co znajduje odzwierciedlenie w tworzonym przez nią tekście. Podobnymi punktami wyjścia do konstrukcji krajobrazu musi dysponować odbiorca tekstu, aby recepcja była udana. Udana oczywiście w kontekście odczytania intencji autora. Indywidualna ocena wartości tekstu podlega innym uwarunkowaniom.

Wśród licznych utworów należących do opisanej grupy chciałabym wybrać dwa wyróżniające się specyficzną narracją.

Kolbuszewski, zajmując się bujdałkami taternickimi oraz ich stymulacją poprzez aktualne tendencje w taternictwie, literaturze czy życiu społecznym, stwierdza, że są one ,subiektywnym dokumentem prawdy, utworem par excellence realistycznym, choć załamującym obraz rzeczywistości nie tylko pod kątem osobistego nastawienia autora" ${ }^{15}$. Można to stwierdzenie odnieść nie tylko do bujdałek. To właśnie specyficzne załamanie obrazu rzeczywistości stanowi o wyjątkowości przykładów, które opiszę.

Utwory te dzieli czas, miejsce akcji, a także pochodzenie autorów. Pierwszy z nich to Brytyjczyk opisujący wyprawy w góry Karakorum z lat osiemdziesiątych

12 J. Kolbuszewski, Taternickie bujdałki. Z dziejów literatury dwudziestolecia międzywojennego, [w:] Literatura i Tatry. Studia i szkice, red. J. Kolbuszewski, Zakopane 2016, s. 647.

13 J.A. Szczepański, Z aktualnych zagadnień taternictwa, „Taternik” 13, 1929, nr 4, s. 83.

14 L. Burckhardt, op. cit., s. 33.

15 J. Kolbuszewski, Taternickie bujdałki..., s. 651. 
XX w., drugi natomiast był polskim wspinaczem przełomu lat pięćdziesiątych i sześćdziesiątych, który jako jeden z nielicznych Polaków miał w owych czasach okazję wspinać się w Alpach. Zacznijmy od tej starszej i bliższej geograficznie pozycji.

Adam Skoczylas (1929-1966) był autorem kilkunastu pierwszych przejść, w tym zimowych, w Tatrach, a także uczestnikiem szwajcarskiej wyprawy na Dhaulagiri w 1960 r. W 1957 i 1959 r. brał udział w wyprawach w Alpy. W czasie pierwszej z nich uczestniczył w osławionej i opisywanej wielokrotnie wyprawie ratunkowej po zespoły włoski i niemiecki na północnej ścianie Eigeru. To właśnie opowiadaniem Stefano, przyjdziemy jutro, tłumaczonym na język angielski i wydanym w Londynie pod tytułem Stefano we shall come tomorrow, którego tematem jest ta akcja ratunkowa, debiutował jako pisarz. Witold Henryk Paryski napisał, że choć akcja ratunkowa na Eigerze stała się tematem licznych literackich relacji, to właśnie Skoczylasowi udało się najlepiej oddać jej atmosferę. W 1962 r. Paryski mówi w tym kontekście o „braterstwie międzynarodowym alpinistów”" Dziś nasze zainteresowanie budzi raczej spontaniczny charakter akcji ratunkowej, w którą włączają się coraz to nowe osoby, i narracja, w której Skoczylas zajmuje się nie tylko samą spektakularną akcją ratunkową, lecz także jej otoczką, szkicując motywy uczestników akcji górskiej i ich pomocników w dolinie, a także zmieniające się postawy. Mocną stroną stylu Skoczylasa jest, jak twierdzi Kolbuszewski, „umiejętność oddania atmosfery niepowtarzalności przeżyć górskich" ${ }^{17}$. Stwierdzenie to napotykamy w recenzji dotyczącej opowiadania Cztery dni stońca, które ukazało się w 1962 r. w zbiorze o tym samym tytule.

Cztery dni słońca to relacja ze wspinaczek w Alpach Berneńskich. Nie są to wybitne przejścia, lecz standardy tamtych czasów, jak północno-wschodnia ściana Aletschhornu czy Jungfrau z Mönchjochhütte. Oceniając ich wyjątkowość, pamiętać należy jednak o historycznym kontekście tej wyprawy: były to czasy, w których wyjazdy w Alpy były drastycznie limitowane, dostępne tylko nielicznym polskim wspinaczom. Dlatego też nawet przejście popularnych dróg wspinaczkowych w tych górach miało posmak niezwykłości. Pomimo to w opowiadaniu Skoczylasa nie znajdziemy wiele informacji o obiektywnych trudnościach pokonywanych ścian czy też o samopoczuciu fizycznym i psychicznym wspinaczy w trakcie górskiego wyczynu. Cztery dni spędzone w górach nie są naznaczone cezurami zdobycia szczytów, sukcesami czy porażkami, lecz stanowią pasmo wrażeń spiętych impresjonistyczną narracją, w której dominuje tryb niedokonany:

Wchodziliśmy na wysokie rdzawe turnie, oddzielające, jak słupy graniczne, świat ciepła od krainy chłodu. Z turni zbiegaliśmy na wąskie przełączki między nimi [...] Potem grań wygładziła się w rozkoszną

16 W.H. Paryski, Adam Skoczylas: Stefano, we shall come tomorrow, „Taternik” 38, 1962, nr 1, s. 42.

17 J. Kolbuszewski, Adam Skoczylas: „Cztery dni słońca”, Taternik 38, 1962, nr 1, s. 42. 
drabinę z chwytów i stopni, przystawioną do niedalekiego już szczytu. Ogarnęła nas radość. Jeden gonił drugiego [...] Niepotrzebną linę odrzucałem spod nóg $[\ldots]^{18}$.

Obiektywne trudności wspinaczki są filtrowane przez aktualne wrażenia:

Byliśmy zmęczeni i o tyle urwisko stało się trudniejsze, przepaścistsze ${ }^{19}$. Wbiłem jeden, drugi, potem trzeci hak. Jak długo stałem obok nich, odgradzały mnie skutecznie od kilometrowej próżni rozpartej na lodowcu. Jednak gdy przyglądałem się im z wysokości dziesięciu metrów, nie mogłem dostrzec w nich nic więcej, jak tylko kruchych podpór, na których ktoś dla zabawy porozwieszał łuki liny ${ }^{20}$.

Odwrócenie uwagi od obiektywnego opisu rzeczywistości górskiej i trudności wspinaczki, i skoncentrowanie się na jej subiektywnym postrzeganiu, implikuje specyficzne środki wyrazu. Opowieść pełna jest zatem impresjonistycznych opisów krajobrazu kształtowanego światłem:

Wreszcie położyłem obie ręce na nawisie. Spojrzałem jeszcze raz w głęboką studnię ściany i wyskoczyłem przez jej najwyższy krąg, wprost na rozsłonecznioną, szeroką grań ${ }^{21}$.

Najbardziej wyrazistą cechą narracji jest chyba koncentracja na własnych wrażeniach zmysłowych o wielkiej intensywności, która zdaje się być tym, co czyni pobyt w górach niezwykłym. Wysiłek w pokonywaniu trudności i ekstremalne warunki nie zatrzymują uwagi autora, służą jakby tylko temu, aby móc silniej odbierać wrażenia. Tak, jak w opisie długiego powrotu rozgrzanym w słońcu lodowcem z Aletschhornu do schroniska Concordia:

Zaczekaj, wyciągnę grejpfruta [...] Przecięliśmy żółtą kulę czekanem. Wyciskałem gorzkawy sok w szeroko otwarte usta. Sok wpływał w uchylone popękane wargi, które piekły jak polane jodyną. Schyliłem się i wytarłem je śniegiem ${ }^{22}$

i ostatniego etapu powrotu, gdy wspinacze docierają do drewnianej (dziś zastąpionej metalową) drabiny prowadzącej do stojącego na wytopionej z lodowca ostrodze skalnej schroniska Concordia:

Zrzuciłem z siebie linę i potoczyłem się do drabiny. Wydobywał się z niej zapach żywicy, jak z krótko przyciętych pni słonecznej poręby.

\footnotetext{
18 A. Skoczylas, Cztery dni stońca, Kraków 2004, s. 67.

19 Ibidem, s. 75.

20 Ibidem.

21 Ibidem.

22 Ibidem, s. 76.
} 
[...] Wokół nas nie było niczego zielonego, tylko martwa buchająca żarem ściana Kammu, a za plecami oślepiająco biały Concordiaplatz ${ }^{23}$.

czy też w czasie samej wspinaczki:

Ciepły granit grzał zmarznięte palce. Wydzielał się z nich przyjemny, ostry zapach pogodnego tatrzańskiego lata. Wspinałem się szybko po brunatnej swojskiej skale ${ }^{24}$.

Miarą górskiego przeżycia jest zatem intensywność wrażeń, a nie przekraczanie obiektywnych i subiektywnych granic. Gdy przyjrzymy się zacy towanym fragmentom, okaże się, że mimo pozornej przystępności, widocznej na przykład w braku fachowego słownictwa, ich właściwą czy też pełną recepcję warunkuje odpowiednie przygotowanie czytelnika polegające na wspólnocie doświadczeń. Dotyczy to nie tylko refleksji nad rozpiętą na hakach liną, lecz także skojarzeń wywoływanych w konkretnej sytuacji przez doznania smakowe i zapachowe. O wartości tekstu decyduje więc umiejętność przekazania tych wrażeń przez narratora.

Cechy takiej narracji zupełnie niespodziewanie pojawiają się w książce, której tematem są cztery ekstremalne wyprawy w Karakorum, przedsięwzięte w latach osiemdziesiątych XX w. Miejsce akcji, którym jest jedno z najmniej poznanych pasm górskich, a także przebieg ekspedycji, które posłużyły za temat książki, dostarczają aż nadto materiału do opisania ich w kategoriach przekraczania granic. Jednak autor wykorzystuje inną strategię. Victor Saunders (ur. 1950) to wybitny brytyjski wspinacz, autor licznych dróg w górach Szkocji i spektakularnych przejść w Himalajach. Napisał również kilka przewodników i dwie książki o swoich wyprawach. Charakterystyczne dla jego pisarstwa jest świadome odwracanie uwagi czytelnika od tego, co przyjęło się przyjmować za wyczyn. W tym kontekście za utwór programowy można by uznać opowiadanie pod tytułem Owcza historia, które Saunders umieścił w tomie Wielkie wspinaczki obok relacji o przełomowych przejściach górskich, takich jak Douga Scotta o zdobyciu Kanczendzongi w stylu alpejskim czy Kurta Diembergera o wyprawie na wschodnią ścianę Everestu. Treść opowiadania stanowi opis obserwowanej przez autora kuriozalnej próby uratowania przez jego kolegów owcy, która zabłąkała się na trudno dostępną półkę skalną.

Nieuchwytne szczyty to cztery relacje z ekspedycji w Karakorum. Już sam tytuł każe skoncentrować uwagę czytelnika na wyprawach, którym nie udało się osiągnąć celu. W czasie trzech pierwszych (na Uzum Brakk, Bojohagur i Rimo) szczyty wymykają się. Czwarta ekspedycja, mająca za cel zdobycie Złotego Filaru Spantika, zostaje zakończona sukcesem. Jednak to właśnie w czwartym opowiadaniu w trakcie zejścia ze szczytu Spantika pojawia się następująca refleksja:

23 Ibidem, s. 77.
24 Ibidem, s. 67.

Góry, Literatura, Kultura 11, 2018

(C) for this edition by CNS 
W tym momencie wydawało mi się, że osiągnięcie szczytu nie ma aż tak dużego znaczenia. Zawsze chcemy dojść do celu, ale zdarza się, że nic $\mathrm{z}$ jego osiągnięcia nie wynosimy ${ }^{25}$.

Natomiast podsumowując wyprawę na Uzum Brakk, którego szczytu nie udało się zdobyć, Saunders notuje:

W ciągu tych 8 tygodni żyłem z intensywnością, której do tej pory nie mógłbym sobie wyobrazićc ${ }^{26}$.

Z tymi stwierdzeniami eksponującymi intensywność przeżyć koresponduje opis wrażeń zmysłowych budujących tę intensywność, spleciony z opisem akcji górskiej. U Saundersa nie znajdziemy jednak tak wielu impresjonistycznych opisów jak u Skoczylasa. Źródeł efektu rozmycia granic należy szukać w innej warstwie tekstu. Akcja górska opisywana jest jako ciąg wydarzeń, w których autor nie eksponuje punktów kulminacyjnych, a raczej nawarstwia obserwacje i doświadczenia, co prowadzi do redukcji cezur czasowych, na przykład gdy stwierdza, że wspomnienia dwóch dni wspinaczki „wymieszały się całkowicie”27. Czas służy mierzeniu odległości, a tydzień, o który odległa jest baza, Saunders przeciwstawia tygodniowi pełnemu różnorodnych wydarzeń o niewielkiej intensywności:

baza była teraz oddalona od nas o cały tydzień schodzenia. Tydzień, w ciągu którego w Londynie pracowałem, rysując nowe elewacje budynków, robiąc specyfikacje, zawierając kontrakty, odpoczywałem ,wspinając się w Gritstone i zabawiałem się wraz z Benem w środowe wieczory w „Globie"28.

Znamienny jest fragment dotyczący aklimatyzacyjnego wejścia na Melangush Chish w czasie wyprawy na Spantik. Po zdobyciu tej stosunkowo łatwo dostępnej góry o wysokości $5800 \mathrm{~m}$ partner Saundersa, Mick Fowler, gratuluje mu jego ,pierwszego himalajskiego szczytu”. Gratulacje nie od razu zostają zrozumiane, wywołując zdziwienie: „Dlaczego ten facet wyciągał do mnie swoje łapska?"29. Epizod ten pełni ważną funkcję — pokazuje, do jakich paradoksów prowadzić może przenoszenie w góry tradycyjnych miar wartości. Saunders jest w czasie wyprawy na Spantik doświadczonym himalaistą, o czym czytelnik dowiaduje się z przeczytanych wcześniej kart książki. W czasie poprzednich wypraw nie zdobył jednak żadnego szczytu. Żartując, Fowler nawiązuje do toposu o zdobyciu szczytu jako nadrzędnego celu pobytu w górach i do tradycji, wedle której alpinistów i himalaistów ocenia się na podstawie łatwo mierzalnych kryteriów. Wykpiwając niestosowny schematyzm, dostarcza narratorowi materiału, a ten relacjonując epizod na szczycie Melagush Chish, demaskuje schemat obecny w literaturze górskiej, wedle którego na uwagę zasługują tylko wydarzenia

25 V. Saunders, op. cit., s. 198.

26 Ibidem, s. 56.

27 Ibidem, s. 126.

28 Ibidem, s. 127.

29 Ibidem, s. 161. 
związane z przekraczaniem wymiernych granic. Jednak rozmycie granic w narracji dotyczącej przeżyć górskich powoduje wytyczenie wyraźniejszej granicy pomiędzy byciem w górach a „resztą życia”.

W opowiadaniu Skoczylasa nagły powrót do domu poznanego w górach francuskiego małżeństwa jawi się jako brutalna ingerencja cywilizowanego świata (Pierre zostaje wezwany przez radiotelefon do swojego pracodawcy w Bordeaux) w oderwany od niego świat przeżyć górskich.

Saunders w kilku miejscach wplata w akcję himalajskich opowieści epizody z życia „W świecie poza górami”. Ich funkcją jest jednak uwypuklenie kontrastu pomiędzy tymi dwoma obszarami życia bohaterów, jak na przykład wtedy, gdy Mick Fowler, będący urzędnikiem w urzędzie podatkowym, informuje Saundersa, architekta z zawodu, o swojej decyzji wzięcia udziału w wyprawie na Spantik:

To było zwykłe urzędnicze biurko. Leżały na nim w wielkim porządku dokumenty i pojemnik na drugie śniadanie, w którym jak zawsze równiutko poukładane spoczywały cztery ciasteczka i dwie grubo krojone kanapki białego pieczywa. Mick Fowler wykręcił numer zrzeszenia miejscowych architektów, równocześnie wkładając sobie do ust kromkę z pasztetem. [...] ja natomiast byłem zajęty poszukiwaniem telefonu przywalonego stertą papierów.

Mick: Odpowiedź brzmi tak.

Vic: A jakie jest pytanie?

Mick: Spantik... ${ }^{30}$

Ta odpowiedź umożliwia przejście granicy do świata gór i narracji o nich.

Ciekawe, że w zakończeniu opowiadania Saunders w ogóle nie wspomina o swoim powrocie, dotycząca jego samego narracja urywa się jeszcze w czasie pobytu w górach. Granicę tę przekracza jego partner, a z kilku zdań kończących opowiadanie można wyczytać dystans, który nagle zaczyna ich dzielić:

A co do Micka, nie wiem, jak udało mu się tak szybko odzyskać siły, ale zdążył na swój samolot. W poniedziałek, punktualnie o godzinie 9.30, siedział już na swym urzędniczym krześle, za swym niewątpliwie urzędniczym biurkiem ${ }^{31}$.

Podobnie Skoczylas, wyprawiając Brigitte i Pierra przez granicę między górami i resztą świata, sprawia, że znikają oni z narracji, co znów ukazuje rozłączność tych dwóch światów. On sam tej granicy w opowiadaniu nie przekracza, choć odbiera zwiastuny przejścia w zmieniającej się pogodzie zapowiadającej koniec słonecznych dni:

Byłem znużony i bezmyślnie patrzyłem na mgłę, która gęstniała, a równocześnie niknął z niej ciepły, pogodny blask. Szarzało z każdą chwilą.

\footnotetext{
30 Ibidem, s. 143-144.

31 Ibidem, s. 200.
} 
— Chodźcie — Zbyszek szarpnął za linę. — Musimy iść dalej32.

Podsumowując, należy stwierdzić, że omawiane utwory zaliczają się do obszaru literatury górskiej, którego granice wytycza z jednej strony specyficzny kontekst tworzenia polegający na ścisłej relacji pomiędzy życiem a pisarstwem, z drugiej zaś specyficzna sytuacja odbioru polegająca na relacji pomiędzy autorem a czytelnikiem opartej na wspólnocie doświadczeń, od której zależy recepcja tekstu.

Czynnikiem stanowiącym warunek powstania takiej literatury było ukształtowanie się specyficznego sposobu patrzenia na góry, wyróżniającego taterników, alpinistów, a potem także himalaistów. Jest on punktem wyjścia dla narracji, a także warunkiem stworzenia odpowiedniej grupy odbiorców. Grupa ta może być bardzo wąska, jak w klasycznych bujdałkach, których recepcja wymaga znajomości realiów epoki, często zaś nie jest w pełni możliwa bez znajomości szczegółowej topografii Tatr, a nawet bez znajomości bohaterów i okoliczności towarzyszących opisywanym wydarzeniom. Względnie szeroką grupę odbiorców zdobyły relacje $\mathrm{z}$ wypraw himalajskich. Wynika to ze spektakularnego charakteru opisywanych wydarzeń, budzącego zainteresowanie mediów, dzięki czemu niektóre książki weszły do szerszego obiegu i bywają czytane poza wąskim kręgiem wtajemniczonych. Problem ich recepcji stanowi natomiast ciekawy dezyderat badawczy.

W obrębie tak wyznaczonego obszaru literatury opisywane przeze mnie utwory wyróżniają się tym, co Kolbuszewski nazywa załamaniem obrazu rzeczywistości pod kątem osobistego nastawienia autora. Autorów obu analizowanych przykładów charakteryzuje koncentracja uwagi na intensywności przeżyć. Czytając ich teksty, odnosimy wrażenie, że to ona jest celem działalności górskiej. Pokonywanie trudności, przedstawiane w innych utworach jako przekraczanie granic, ma wartość tylko o tyle, o ile pozwala intensywniej przeżywać pobyt w górach i odbierać wrażenia. Natężenie wrażeń nie musi być jednak wcale proporcjonalne do trudności. Trudno oprzeć się odczuciu, że obu autorów odrzucają miary funkcjonujące w zwykłym świecie, takie jak wysokość, ilość czy wydolność fizyczna lub psychiczna, a tym samym wyznaczane przez nie granice. Jedyna istotna granica to ta oddzielająca góry od reszty świata.

Sam Saunders podsumowuje:

Góry były taką bezludną, nierealną planetą, którą przeżywa się jak książkę i którą opuszcza się w momencie, gdy zamyka się jej okładki ${ }^{33}$.

\footnotetext{
32 A. Skoczylas, op. cit., s. 80.

33 Ibidem, s. 101.
} 